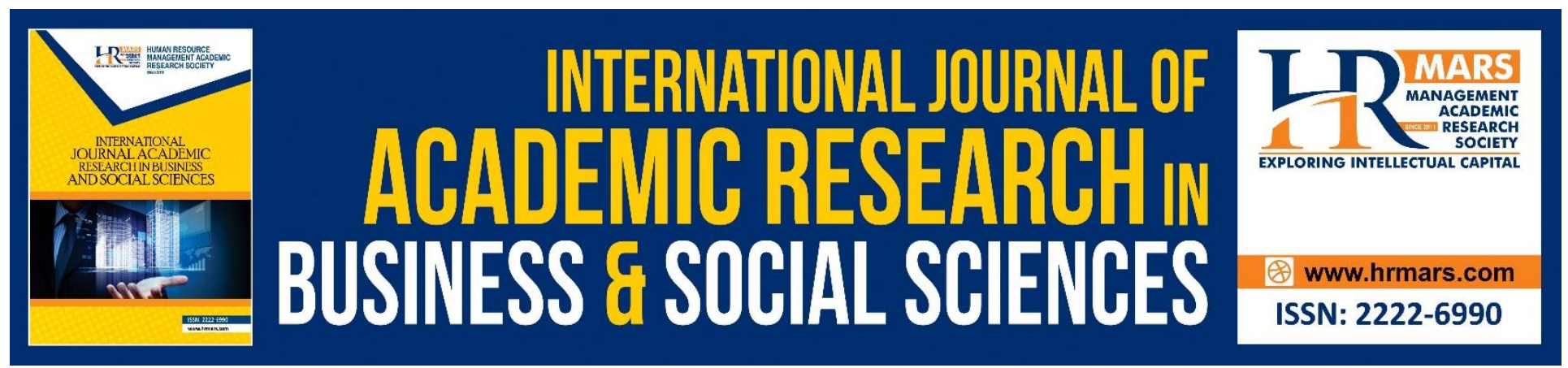

\title{
Implementation Strategy of Harmony between Ethnics among Youths in Malaysia through National Service
}

Mohd Mahadee Ismail, Mansor Mohd Noor, Nor Azlili Hassan, Nor Hafizah Abdullah, Azlina Abdullah

To Link this Article: http://dx.doi.org/10.6007/IJARBSS/v10-i8/7538

DOI:10.6007/IJARBSS/v10-i8/7538

Received: 03 May 2020, Revised: 06 June 2020, Accepted: 09 July 2020

Published Online: 19 August 2020

In-Text Citation: (Ismail, Noor, Hassan, Abdullah, \& Abdullah, 2020)

To Cite this Article: Ismail, M. M., Noor, M. M., Hassan, N. A., Abdullah, N. H., \& Abdullah, A. (2020).

Implementation Strategy of Harmony Between Ethnics Among Youths in Malaysia Through National Service. International Journal of Academic Research in Business and Social Sciences. 10(8), 283-294.

Copyright: (C) 2020 The Author(s)

Published by Human Resource Management Academic Research Society (www.hrmars.com)

This article is published under the Creative Commons Attribution (CC BY 4.0) license. Anyone may reproduce, distribute, translate and create derivative works of this article (for both commercial and non-commercial purposes), subject to full attribution to the original publication and authors. The full terms of this license may be seen

at: http://creativecommons.org/licences/by/4.0/legalcode

Vol. 10, No. 8, 2020, Pg. 283 - 294

http://hrmars.com/index.php/pages/detail/IJARBSS

JOURNAL HOMEPAGE

Full Terms \& Conditions of access and use can be found at http://hrmars.com/index.php/pages/detail/publication-ethics 


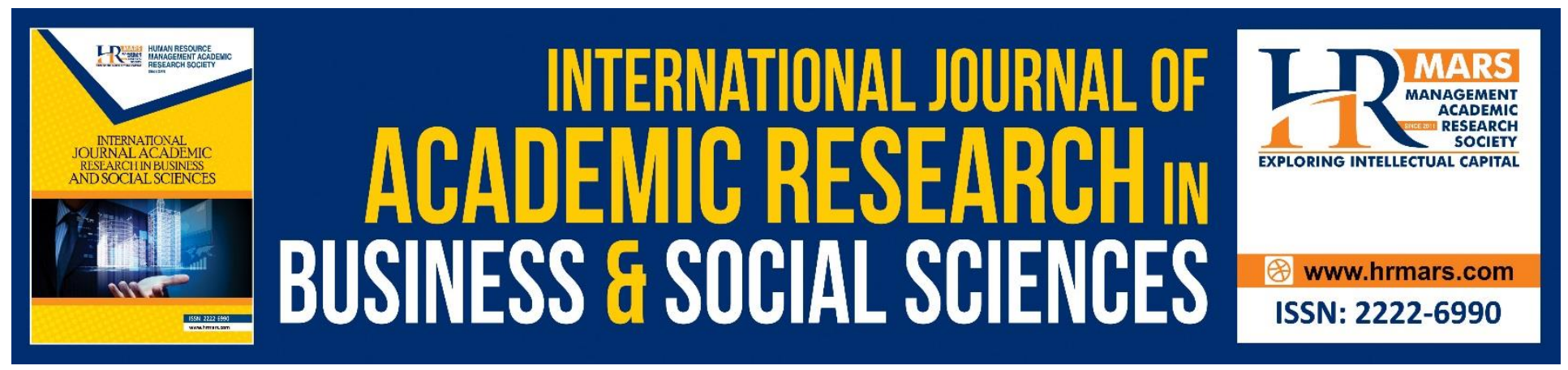

\title{
Implementation Strategy of Harmony Between Ethnics Among Youths in Malaysia Through National Service
}

\author{
Mohd Mahadee Ismail \\ University Putra Malaysia, Selangor, Malaysia (UPM) \\ Mansor Mohd Noor \\ Universiti Kebangsaan Malaysia, Selangor, Malaysia (UKM) \\ Nor Azlili Hassan \\ Universiti Tunku Abdul Rahman, Selangor, Malaysia (UTAR) \\ Nor Hafizah Abdullah \\ Universiti Sultan Zainal Abidin, Terengganu, Malaysia (UniSZA) \\ Azlina Abdullah \\ Universiti Kebangsaan Malaysia, Selangor, Malaysia (UKM) \\ Email: hafizahabdullah@unisza.edu.my
}

\begin{abstract}
This paper discusses the implementation strategy to achieve harmony between ethnic groups among the Malaysian youths. The study focuses on Universiti Putra Malaysia (UPM) students who have joined the National Service Training Program (PLKN). PLKN is a national agenda which aims to train the young people to be an excellent future generation, especially in the context of multiethnic Malaysians. The main goal of PLKN's implementation is; (i) to enhance the spirit of patriotism and love the nation among the younger generation; (ii) to foster national unity and national integration; (iii) to develop positive character through the application of good values; (iv) to promote the spirit of volunteerism among the youth; and $(\mathrm{v})$ to produce a young generation with strong physical and mental as well as high self esteem. There are 207 respondents participated in this study which is comprising of Malay and Chinese youths. The findings show that almost all measured dimensions are at a high level of intensity. The intensity of the Malay youths was higher than the Chinese youths. In general, the implementation of PLKN is the best strategy in establishing harmony among ethnic groups, especially among youths who are the future generation of the nation. However, the national
\end{abstract}


INTERNATIONAL JOURNAL OF ACADEMIC RESEARCH IN BUSINESS AND SOCIAL SCIENCES Vol. 10, No. 8, 2020, E-ISSN: 2222-6990 @ 2020 HRMARS

service program has been abolished after the conversion of the federal government in the 14th General Election.

Keywords: Harmony, Ethnic Relation, Youth \& National Service.

\section{Introduction}

Malaysia, as a multiethnic society, always faces various challenges in the societal life. The variances of the Malays, Chinese, Indians and other indigenous people have affected inter-ethnic relations among the Malaysian multiethnic societies due to the diversity of identities, customs, and traditions, as well as beliefs and lifestyles (Ismail et al.,2019). Furthermore, the current challenges through the era of globalization that struck the world has now increased the diversity of Malaysian society in Malaysia. The formation of national identity is also very important in order to eradicate the problems related to multiethnic relationship (Ismail et al.,2019). Therefore, various action plans and strategies have been implemented by the government in creating and maintaining harmony among the ethnic groups. According to Suffian, et al., (2017) many countries including Malaysia invest in planning and implementing various programs to educate and propel youth to greater heights. One of the strategies implemented is the National Service Training Program (PLKN) as a framework for developing youths comprehensively in all aspects of life. Young people are the future generation of the nation that need to be given special attention consistently. According to records from the Department of Statistics, Malaysia (2017), the total number of populations aged between 15 to 19 is about 2,873,000 while the total number aged between 20 to 24 is about 3,251,000 from the whole population of 32,049.7 million. Individuals aged between 20 to 24 are the group scattered for both genders of males and females (Department of Statistics, Malaysia, 2017).

\section{Implementation of the National Service Training Program (PLKN)}

The implementation of PLKN has the ultimate goal in achieving a comprehensive unity in the life of Malaysian multiethnic society. The effort should be applied in realizing the construction of a desired nation-state (Jayasankaran, 2004; Ismail, 2015). Its implementation becomes a national agenda to train the young generation to be an excellent, and glorious in the future. The successful of developing the today's younger generation is a benchmark for future development of the country. In catalyzing the implementation of a nation-service program, several approaches have been adopted, including;

(i) The implementation is based on the principles of Rukun Negara as the national ideology which is the foundation of the Malaysians. PLKN focuses the observation and practice of the principles of Rukun Negara as a harmonious way of living in a society.

(ii) The formation of a multidisciplinary curriculum by focusing on holistic human development in life to face the everyday challenges. PLKN's curriculum is not deprived of force, or military conscript in nature but is characterized to educate, construct, and learn the process through experience. Therefore, PLKN does not contain punishment in the form of torture but imposes punishments aimed at teaching.

(iii) The training period only takes three months which involving youths from various ethnics, genders, and religious backgrounds. The participation is voluntary and those interested may submit the application from time to time based on the appointed date. The age of the trainee is between 16 
INTERNATIONAL JOURNAL OF ACADEMIC RESEARCH IN BUSINESS AND SOCIAL SCIENCES Vol. 10, No. 8, 2020, E-ISSN: 2222-6990 @ 2020 HRMARS

to 35 years old, but is more targeting to Sijil Pelajaran Malaysia (SPM) students aged between 17 to 18 years old.

(iv) Implementation of PLKN is held in training camps and dormitories that allow trainees to interact and know with one another, as well as to understand and tolerate their differences. Therefore, the National Service Training Department (JLKN) sets the number of trainees in each camp between 300 to 400 persons.

(v) PLKN brings and reflects its own image and identity. This can be seen through its customdesigned army uniforms, symbols, mottoes, logos, and songs. For example, the concept of the logo that is highlighted is a burning fire symbolizing the spirit of deep and strong patriotism.

(vii) PLKN trainer is based on his expertise and experience. Most PLKN trainers are the members of the Malaysian Armed Forces (ATMs) and certified coaches from military retirees, university graduates, as well as public and private sector officials. All PLKN trainers must undergo and pass the Training of Trainers (TOT) courses based on the established modules. In order to enhance the excellence and quality of the trainers, the JLKN also organizes courses of expertise and refresher courses to their trainers.

(viii) The Naziran Group has been established as a program observer and will be chaired by National Service Council (MLKN) member that consists of several special appointees. The role of this group is to ensure that the implementation of the program meets the established standards, monitor the progress of the trainers, and review the implementation of the training modules.

The implementation of PLKN's approach with the mix of 'military' and 'volunteerism' makes this program attractive, comprehensive, and holistic. The process of 'learning through experience' gives the opportunities for trainees' experience and appreciate themselves on every activity that is applied during the training. Clearly, this program is not giving burden and boring but it is well-aligned with the mentality of the trainees at that age level which is still easy to flex and educate.

\section{Objective of National Service Training Program}

By referring to the JLKN website, the government has outlined some of the following objectives to be achieved through PLKN, namely;

(i) Enhance the spirit of patriotism and love the nation among the young generation.

(ii) Foster national unity and integration.

(iii) Form a positive character through good values.

(iv) Strengthen the spirit of volunteerism among the adolescents.

(v) Producing a strong, intellectual, and high self-esteem of young generation (www.khidmatnegara.gov.my/plkn/objektif/).

\section{Study on Implementation of National Service}

The study on national services has been carried out by previous researchers such as Aziz et al. (2004); Ibrahim (2004); Muhammad et al. (2004); Hussin et al. (2005); Abdullah et al. (2006); Yahya et al. 
INTERNATIONAL JOURNAL OF ACADEMIC RESEARCH IN BUSINESS AND SOCIAL SCIENCES Vol. 10, No. 8, 2020, E-ISSN: 2222-6990 @ 2020 HRMARS

(2005); Herman et al. (2006); Ismail et al. (2009); Aziz et al. (2004); (Darwish, Abdo, \& AlShuwaiee, 2018) has focused on the idea of statehood in PLKN. Statistically, their study found that there has been an increase in the level of nationalism, patriotism, unity, and significant concern among PLKN trainees. In the meantime, the study also found that there were differences in perceptions from different ethnic groups regarding the measured state element (Aziz et al., 2004). The study by Ibrahim (2004) has evaluated the goals and the implementation of PLKN which stated that the goals of the program are unclear and majority of the trainees are still immature, adopting a free social lifestyle, over thinking of pleasure and having a low religious attitude which then has affected the achievement of PLKN's goals. While the study by Muhammad et al. (2004) has identified that there are religious elements applied in PLKN, as well as in its approach and implementation in the program. His findings show that the application and approach of religion in PLKN is still not comprehensive and insufficient based on the current situation of the Malaysian society that comprising of religious and ethnic diversity. In addition, study by Hussin et al (2005) which focuses on the management and administration of PLKN, found that the implementation of PLKN is effective in developing a young generation which has successfully fostered the spirit of patriotism and the love of the nation through various forms of physical and mental activity, character building approaches, state modules and community activities.

Abdullah et al. (2006) has focused on the study of state values among PLKN trainees and found that the male trainees show a higher value of patriotism, unity and volunteerism than the female trainees. In terms of ethnic composition, the trainees among the aborigenes showed a high patriotism while the Malay trainees showed the low value of patriotism (Abdullah et al., 2006). Meanwhile, the study by Yahya et al. (2005), has evaluated PLKN through the idea of physical training which found that min spirit decorps and self-confidence showed a very small increase at the end of the training program. The mean value of self-esteem and leadership skills at the end of the program is relatively lower than the mean of the program (Yahya et al., 2005). Based on gender, the training effectiveness of female physical trainees is better than male trainees (Yahya et al., 2005).

The study by Herman et al. (2006) revolves around the effectiveness of PLKN through psychological ideas. Their findings show that there is significant improvements in the personality aspects of the trainees, and there is a relatively small increase in the leadership aspect at the end of the training program. On the other hand, the idea of good values and self-esteem shows a decrease in the end of the training (Herman et al., 2006). This situation explains that the idea of good values and self-esteem cannot be improved within three months of PLKN training (Herman et al., 2006). The effectiveness of the training through this psychological idea also illustrates that female trainees have a higher moral values and self-esteem than male trainees (Herman et al., 2006). Furthermore, the study by Ismail et al. (2009) found that the appreciation level of the spirit of patriotism and nationalism among PLKN trainees is generally at a high level and can be proud of. However, the study specifically found that the involvement in PLKN did not contribute significantly to the spirit of patriotism and nationalism (Ismail et al., 2009). This is because the spirit of patriotism and nationalism among PLKN trainees has been at a good level before they undergoing the PLKN program. 
INTERNATIONAL JOURNAL OF ACADEMIC RESEARCH IN BUSINESS AND SOCIAL SCIENCES Vol. 10, No. 8, 2020, E-ISSN: 2222-6990 @ 2020 HRMARS

\section{Methodology}

The study employs quantitative approaches through survey techniques by using questionnaires. The sample of the study was among the students in Universiti Putra Malaysia (UPM), who are the alumni of PLKN. The snowball techniques were used in the distribution of questionnaires to obtain the respondents who had participated in PLKN. As a result, the total of 207 PLKN alumni have been participated in this study which is 115 Malay students and 92 Chinese students. This study focuses only on the Malay and Chinese youth groups as the two ethnic groups are the dominant group in Peninsular Malaysia (Ismail, 2015). The analysis applied is descriptive by using percentage.

\section{Implementation Strategy of Harmony Between Ethnic Among Youth in Malaysia}

The era of borderless world, with full of modernity and high technology, has brought great changes to society and the nation. The changes have not only changed the value of the society towards being more individualistic and materialistic (Oesterle et al., 2004) but also has led the society to ignore their surroundings (Wasitah, 2013) that could affect the harmony between the ethnics. This is proven in Malaysian Youth Index (IBM), that produced by the Malaysian Youth Development Research Institute (IPPBM), as a parameter in measuring nine youth welfare domains has shown a drop in 2011 score of 65.4 percent compared to 2008 score of 67.4 percent (Wasitah, 2013). Due to this unsatisfactory situation, the government has launched a multi-dimensional approach to enhance the involvement of the society, particularly the youths, in community activities.

In the beginning, many community programs and activities were established with the involvement of the Malaysian Youth Council (MBM), and various Non Govermental Organization (NGO) movements such as Salam Foundation and Malaysian Relief Agency. On top of that, the government has implemented other initiatives such as Rakan Muda, Skuad Muda Rela, Crime Awareness Team (CAT), Anugerah Remaja Perdana, MyCorps and 1Malaysia For Youth (IM4U) approach. The implementation of these various approaches has raised the spirit of the young to contribute services to religion, race, and nation. For instance, the My Beautiful Malaysia Day 2013 program that has been implemented through IM4U received a very encouraging response. This was proven through a study conducted on 3691 youth respondents, where 96.8 percent felt that the activities carried out had prompted them to remain active in the community services (Shariffah, 2013).

Meanwhile, through the national service program, the efforts to enhance ethnic harmony have been considered as the main agenda. Implementation of national services is a mechanism to strengthen the national identity and to express the feelings of unity. Thus, various forms of national service programs that implemented in various countries such as Singapore, South Korea and Thailand have applied the form of military force deployments (Ismail, 2015). However, national service programs in India, South Africa and Brazil are more voluntary in nature (Ismail, 2015). The main aim of national service in India, for instance, is to raise awareness amongst their students about the reality of life, to create an understanding about the society and to explore the problems of the people as well as to develop their personality (Abraham, 2010; Ismail, 2015). South Africa and Brazil provide opportunities for their young generations to engage in the activities that benefit the community (Fehnel et al., 2000; Brooke et al, 2000; Ismail, 2015). While the implementation of national service in Malaysia embraces the form of military and volunteerism services. 
INTERNATIONAL JOURNAL OF ACADEMIC RESEARCH IN BUSINESS AND SOCIAL SCIENCES Vol. 10, No. 8, 2020, E-ISSN: 2222-6990 @ 2020 HRMARS

In order to measure the implementation strategy of harmony between ethnics among youths through PLKN, there are five dimensions have been used, including; (i) the spirit of patriotism and the love of the state; (ii) ethnic unity and national integration; (iii) positive character through good values; (iv) voluntary spirit; and ( $v$ ) a young generation with strong, intelligent and high self-esteem.

\section{Enhancing the Spirit of Patriotism and Love of the State among Young Generation}

The efforts to enhance the spirit of patriotism and love of the state among youths are strengthened from time to time. These efforts are emphasized through the implementation of the PLKN Be Safe Be Alert Module which aims to instill the sense of pride in every individual who are the Malaysian citizens while providing an understanding of responsibility as a citizenship. In the meantime, this module aims to assure that the trainees will appreciate the current peaceful surroundings, reject any forms of threats that could jeopardize national security, appreciate the history of the nation's struggles pioneered by previous generations and respect the leader of the country.

In addition, the implementation of MalaysiaKu Module is also aimed at strengthening the spirit of patriotism based on the experience happened in the country. The implementation of this module is expected to raise awareness among the individuals about the importance of unity as a Malaysian nation based on the Malaysian Constitution and the principles of Rukun Negara. At the same time, the MalaysiaKu Module aims to build the identity of the trainees so that they will not be easily influenced by external elements that could undermine the unity of all ethnic groups.

Table 1: Spirit of Patriotism and Love of the State

\begin{tabular}{|l|c|c|c|}
\hline & Sense of Belonging (\%) & $\begin{array}{c}\text { Patriotisme } \\
\text { (\%) }\end{array}$ & Historical Sharing (\%) \\
\hline Malay & 98.3 & 93 & 94.8 \\
\hline Chinese & 82.6 & 71.7 & 97.8 \\
\hline
\end{tabular}

Based on Table 1, the findings on the spirit of patriotism and the love of the state, that has been implemented through the PLKN, shows a very positive achievement. The Malay respondents showed excellent level of intensity for all measured dimensions which is more than 90 percent. Meanwhile, Chinese respondents showed a good level of intensity for the historical sharing dimension and sense of belonging, but moderately good for the dimension of patriotism.

\section{Cultivation of Ethnic Unity and National Integration}

In cultivating ethnic unity and national integration, PLKN has implemented the Fit4Life Module with the primary focus in building individual skills, mental resilience, emotional, spiritual, and physical stability. Explicitly, this module aims to create awareness and improve the quality and performance of individuals in terms of health, nutrition, and physical fitness. Implicitly, the forms of training, regardless of ethnic differences, can strengthen unity and foster integration among the trainees. This module encompasses various forms of military-style, sports, leisure, and traditional games that instill collaborative elements and teamwork. 
INTERNATIONAL JOURNAL OF ACADEMIC RESEARCH IN BUSINESS AND SOCIAL SCIENCES Vol. 10, No. 8, 2020, E-ISSN: 2222-6990 @ 2020 HRMARS

In addition, during the three-month training camps, the trainees need to do their daily activities together thus they can develop a sense of co-operation, tolerance, respect, and understand the difference between them. They are exposed and trained with the characteristics of a multiethnic nation of Malaysia as a strength to the country.

Table 2: Ethnic Unity and National Integration

\begin{tabular}{|l|c|c|c|c|}
\hline & Cooperation (\%) & Respect (\%) & $\begin{array}{c}\text { Tolerance } \\
\text { (\%) }\end{array}$ & $\begin{array}{c}\text { Malaysian Nation or } \\
\text { Bangsa Malaysia (\%) }\end{array}$ \\
\hline Malay & 95.7 & 97.4 & 80.9 & 98.3 \\
\hline Chinese & 90.2 & 95.7 & 60.9 & 96.7 \\
\hline
\end{tabular}

Based on Table 2, the findings on the ethnic unity and national integration that has been applied in PLKN shows a proud achievement. The $90 \%$ of the respondents for both Malay and Chinese ethnics showed a positive intensity for the three measured dimensions namely, cooperation, respect and Malaysian nation or Bangsa Malaysia. However, the intensity for the tolerance of the Malay respondents is only 80 percent compared to the Chinese respondents' intensity which is only 60 percent.

\section{Formation of Positive Character Through Good Values}

PLKN has implemented the I-Upgrade Module and the Spiritual Module in order to create a positive character through the application of good values. The I-Upgrade module aims to nurture seven core values for self-development, establish good relationships with the others and form a contribution that can be distributed to the community. Through this module, trainees are given the understanding and awareness about the core values by using artistic and creative approaches such as acting, poetry, quizzes, presentations, drawings and so forth.

The Spiritual Module is implemented to foster awareness for all trainees and to appreciate the good values in their life. The implementation of this module involves all Muslim, Christian, Buddhist and Hindu trainees towards the formation of holistic human capital. The trainees are given an understanding of the good values and the importance of religious life as claimed by the teachings of their respective religions. The trainees are taught on how to apply the noble morals through the religious history, prayer activities and practices of special doa.

Table 3: Positive Character Through Good Values

\begin{tabular}{|l|c|c|c|}
\hline & Honesty (\%) & Courage (\%) & Positive Thinking (\%) \\
\hline Malay & 93.5 & 90.4 & 93.9 \\
\hline Chinese & 88.1 & 78.3 & 75 \\
\hline
\end{tabular}

Based on Table 3, the result of positive character through the application of good values in life, as already applied in PLKN, shows a proud achievement for the Malay respondents and moderately good for the Chinese respondents. The Malay respondents show a high intensity of the three measured dimensions, namely honesty, courage, and positive thinking, which is 90 percent and above. 
INTERNATIONAL JOURNAL OF ACADEMIC RESEARCH IN BUSINESS AND SOCIAL SCIENCES Vol. 10, No. 8, 2020, E-ISSN: 2222-6990 @ 2020 HRMARS

Meanwhile, the Chinese respondents showed the intensity levels at around 75 percent to 88 percent for all measured dimensions.

\section{Enliven the Voluntary Spirit among Youth}

The application of the voluntary spirit is one of the main thrusts through national service program. In this regard, PLKN has implemented a Learning Service Module which is aimed at developing soft skills, improving the spirit of nationality, as well as nurturing the identity that is always ready to contribute to the society and spirit of volunteerism. This module is designed specifically to educate the trainees to plan, implement and undertake the community service projects to the local communities. Through the implementation of this module, the trainee is exposed to empathy values, engaging in good deeds and willing to provide assistance to those in need.

Table 4: Voluntary Spirit

\begin{tabular}{|l|c|c|c|}
\hline & $\begin{array}{c}\text { Volunteerism } \\
\text { (\%) }\end{array}$ & $\begin{array}{r}\text { Ready to Help } \\
(\mathbf{\%})\end{array}$ & $\begin{array}{c}\text { Community Participation } \\
\text { (\%) }\end{array}$ \\
\hline Malay & 88.7 & 96.5 & 52.2 \\
\hline Chinese & 67.4 & 80.4 & 42.4 \\
\hline
\end{tabular}

Based on Table 4, the result of the voluntary spirit which is applied in PLKN, has shown an equally accomplished achievement. The Malay respondents show a positive intensity level for ready-to-help dimensions, good intensity for the dimension of volunteerism and relatively low for dimension of community participation. While the findings on the Chinese respondents show a good intensity level for ready-to-help dimensions, moderately good for dimension of volunteerism and relatively low for dimension of community participation.

\section{Creation of a Strong, Intelligent and High Self-Esteem Young Generation}

The PLKN's approach in creating a more strong, intelligent, and high self-esteem young generation has been implemented through the Fit4Life and My Future Module. The Fit4Life module aims to enhance the mental strength for self-survival, self-discipline, leadership, self-confidence, teamwork skills and a high spirit of friendship. Implementation of this module will not only help the trainees to make the right decision in determining their future direction, healthy lifestyle, and a spirit of selfreliance, but also to construct a creative, strategic and innovative thinking. These elements are very important in ensuring the future survival.

The My Future module has the goal in exposing the understanding to the trainees that life is always colored with a variety of choices. In addition, this module also teaches the trainees in identifying their interests and tendencies. From self-interest and inclination, the trainees are taught to pursue their dreams of becoming a successful professional in the future. Thus, the trainees must always be strong, intelligent, and high self-esteem to express their personal dreams.

Table 5: Strong, Intelligent and High Self-Esteem Young Generation

\begin{tabular}{|l|c|c|c|}
\hline & Self-Discipline (\%) & $\begin{array}{c}\text { Self-Confidence } \\
\text { (\%) }\end{array}$ & Leadership (\%) \\
\hline Malay & 86.1 & 92.2 & 93.7 \\
\hline Chinese & 85.9 & 89.6 & 92.4 \\
\hline
\end{tabular}


INTERNATIONAL JOURNAL OF ACADEMIC RESEARCH IN BUSINESS AND SOCIAL SCIENCES Vol. 10, No. 8, 2020, E-ISSN: 2222-6990 @ 2020 HRMARS

Based on Table 5, the results of a strong, intelligent, and high self-esteem young generation, as implemented through PLKN, demonstrate a positive achievement for all measured dimensions namely, self-discipline, self-confidence, and leadership. The intensity of the Malay respondents is slightly better than the intensity of Chinese respondents for all measured dimensions.

\section{Main Findings}

Overall, the implementation of PLKN is the best strategy for creating and maintaining harmony among the ethnic groups, particularly among youths in Malaysia. Application of the Fit4Life, Service Learning, I-Upgrade, Be Safe Be Alert, Tech Talk, MalaysiaKu, My Future and Spiritual module have improved the spirit of patriotism, ethnic unity and national integration, positive character, voluntary spirit and self-esteem. This is proven through findings that show high intensity rates for most measured dimensions. Although there are several dimensions held at moderate intensity of good or low, but it does not affect the goal of PLKN's implementation in realizing the formation of a Malaysian nation-state.

The implementation of PLKN is seen to be comprehensive in order to continuously harmonize the multiethnic society in Malaysia through a centralized consolidation process in all training camps and the learning process through experience. The effort coincided with the concept of national service that provided a platform for the young generation of different communities and ethnic groups in creating a new spirit of unity and strong national identity, high self-respect, and loyalty to the beloved country (Grigsby, 2008). In the meantime, the application of national service can create a sense of belonging particularly in a society and among the youths who are viewed as being individualistic and selfish (Smith, 1990). In addition, national service becomes a medium and civic responsibility sharing method that binds the community together in a strong manner (Moskos, 1988), promotes the reconstruction of patriotism (Janowitz, 1983) and is a moral development program that forms collective self-discipline and responsibility (Smith 1990). National service is also a mechanism for inculcating community service, volunteering services and the best approach to address social issues that are mostly related to the young generation (Smith 1990). Therefore, the implementation of national services by the government has significant implications for the long-term in building a brilliant, glorious and distinguished identity especially among youths who will be the future of the nation (Ismail et al., 2016).

The implementation of national service is actually a new platform as a political socialization agent, because its approach is not only fosters racial harmony among the youths but is also a basic mechanism in applying political literacy, cultivating a high patriotic spirit and being a catalyst for the building of a united Malaysian (Ismail, 2015). The 'learning process through experience' approach opens a wider social spectrum for the young generation to interact and know each other closely. This is in line with a new approach in political socialization that assumes the youth development programs as a more effective political socialization agency (Youniss, 2005). In fact, youth development programs that are practiced outside the learning period, outdoor activities at training camps and weekend programs are seen as fun, interesting and have a greater impact on the development of youth identity. Such forms of program may also be an additional political socialization agent towards the traditional agents and complementary to all the weaknesses of those agents (Youniss, 2005). 
INTERNATIONAL JOURNAL OF ACADEMIC RESEARCH IN BUSINESS AND SOCIAL SCIENCES Vol. 10, No. 8, 2020, E-ISSN: 2222-6990 @ 2020 HRMARS

\section{Conclusion}

The implementation of PLKN which is based on national service makes it an attractive program, contains many benefits, not burdensome, not boring and well-aligned with the thinking of a young trainee. The approach taken was not only as a implementation strategy of harmony between ethics among the youths, but also a mechanism that strengthens the foundations of national identity and binds the people to a national platform. The process of 'learning through experience' approach gives a broad social spectrum to the trainees in experiencing a multi-ethnic life exposure, more familiar with each other, showing a high tolerance and understanding the differences between them. The importance of PLKN is to enhance the spirit of patriotism, to foster national unity and integration, to create a positive character, to embark on the spirit of volunteerism and to produce a quality young generation. In fact, there are other elements that are implied in the implementation of PLKN such as to deal with social changes that occur in society, creating civic consciousness and building a unified nation-state. However, the national service program has been abolished after the federal government's conversion in the 14th General Election as its implementation involves high expenditures.

\section{References}

Abdullah, M. A. I. L., Aziz, A. R. A., Ishak, M. S., \& Brahim, M. (2006). Laporan Kajian Nilai-nilai Kenegaraan Dalam Kalangan Pelataih-Pelatih Khidmat Nehara Siri Empat. Research Report. Sintok: Pusat Penyelidikan Dan Perundingan, University Utara Malaysia.

Aziz, A. R. A., Ishak, M. S., Brahim, M., \& Abdullah, M. A. I. L. (2004). Penyelidikan Program Khidmat Negara Dari Aspek Gagasan Kenegaraan. Research Report. Sintok: Pusat Penyelidikan dan Perundingan, Universiti Utara Malaysia.

Darwish, S., Abdo, H., \& AlShuwaiee, W. M. (2018). Opportunities, challenges and risks of transition into renewable energy: the case of the Arab Gulf Cooperation Council. International Energy Journal, 18(4).

Government of India. (2006). National service scheme manual (Revised). New Delhi: Ministry of Youth Affairs \& Sports.

Grigsby, C. A. (2008). Binding the nation: National service in America. Parameters 38(4): 109-123.

Herman, I., Noor, A. B. M., Samat, H., \& Shaari, A. (2006). Penilaian Program Latihan Khidmat Negara melalui Gagasan Psikologi. Research Report. Universiti Utara Malaysia.

Hussin, Z., Shamsuddin, K. B., Ismail, N., \& Awang, A. B. (2005). Kajian Tinjauan mengenai Kaedah Pengurusan dan Pengendalian Program Latihan Khidmat Negara. Research Report. Institut Penyelidikan, Pembangunan dan Pengkomersilan, Universiti Teknologi MARA.

Ibrahim, M. A. A. (2004). Kajian Program Latihan Khidmat Negara (Kumpulan 'Hardcore'). Research Report. Universiti Sains Islam Malaysia.

Ismail, M. M., Othman, Z., Hassan, N. A., Abdullah, N. H., \& Zan, M. U. M. S. (2019). Nation-building among youths in Malaysia:The civic education approach. Journal of Nusantara Studies, 4(2), 390-409. http://dx.doi.org/10.24200/jonus.vol4iss2pp390-409

Ismail, M. M., Noor, M. M., \& Othman, Z. (2016). Program Latihan Khidmat Negara (PLKN): Wadah Baru Sosialisasi Politik. Research Journal of Social Sciences, 9(3): 28-36.

Ismail, M. M., Noor, M. M., \& Othman, Z. (2016). Program Latihan Khidmat Negara (PLKN): Wadah Baru Sosialisasi Politik. Research Journal of Social Sciences, 9(3): 28-36. 
INTERNATIONAL JOURNAL OF ACADEMIC RESEARCH IN BUSINESS AND SOCIAL SCIENCES Vol. 10, No. 8, 2020, E-ISSN: 2222-6990 @ 2020 HRMARS

Ismail, M. M. (2015). Pendidikan Sivik dan Pembinaan Etos Nasional dalam kalangan Alumni Program Latihan Khidmat Negara (PLKN): Kajian ke atas Mahasiswa Universiti Putra Malaysia (UPM). PhD Thesis, Institute of Ethnic Studies, Universiti Kebangsaan Malaysia.

Ismail, M. M., Jawan, J., Ahmad, Z., Halim, A. A., \& Singh, S. S. D. (2009). Penghayatan Semangat Patriotisme dan Nasionalisme: Pelatih Program Latihan Khidmat Negara (PLKN). Sciencefund Report, Kementerian Sains, Teknologi dan Inovasi Malaysia.

Ismail, M. M., Abdullah, M. S., \& Noor, M. M. (2015). Signifikan Implementasi Program Latihan Khidmat Negara (PLKN) di Malaysia. Jurnal Kinabalu 20: 147-175.

Jabatan Latihan Khidmat Negara. (2008). Annual Report. Kuala Lumpur: Jabatan Latihan Khidmat Negara.

Jabatan Perangkaan Malaysia. (2017). https://www.dosm.gov.my/v1/

Janowitz, M. (1983). The Reconstruction of Patriotism. Chicago: University of Chicago Press.

Jawatankuasa Pilihan Khas Mengenai Perpaduan dan Khidmat Negara. (2007). Laporan Jawatankuasa Pilihan Khas Mengenai Perpaduan dan Khidmat Negara: Ringkasan Program Latihan Khidmat Negara (PLKN). Kuala Lumpur: Jabatan Latihan Khidmat Negara.

Jayasankaran, S. (2004). Nation-building. Far Eastern Economic Review 167(5): 20.

Moskos, C. C. (1988). A call to civic service: National service for country and community. New York: The Free Press.

Muhammad, Y. K., Ibrahim, M. A. A., Muda, M., Ibrahim, C. W. C. C. W., Zarif, M. M. M., Omar, A. T. S., Subr, I. M., \& Rahman, A. A. (2004). Kajian Program Latihan Khidmat Negara (Aspek Agama). Research Report. Kolej Universiti Islam Malaysia.

Oesterle, S., Johnson, M. K., \& Mortimer, J. T. (2004). Volunteerism during the Transition to Adulthood: A Life Course Perspective. Social Forces 82 (3):1123-1149.

Shariffah, M. (2013). Sukarelawan: My Beautiful Malaysia Day 2013. Buletin Institut Penyelidikan Pembangunan Belia Malaysia. 1st Edition 2013. Putrajaya: Kementerian Belia dan Sukan.

Smith, T. W. (1990). National service. The Public Opinion Quarterly 54(2): 273-285.

Suffian, H. A., Hamzah, M. R., Azmy, S. N. M. S., Abdullah, N. H., Hayyi, W. O., Salim, H., \& Wahab, Z. (2017). Sexual Health Communication Among Youth: A Study of Knowledge And Attitude, Jurnal Komunikasi: Malaysian Journal of Communication, pp. 234-248, ISSN: 2289151X https://doi.org/10.17576/JKMJC-2017-3304-15

Wasitah, M. Y. (2013). Kesukarelaan. Buletin Institut Penyelidikan Pembangunan Belia Malaysia. 1st Edition 2013. Putrajaya: Kementerian Belia dan Sukan.

Yahya, D., Shaari, A. S., \& Ajis, M. N. (2005). Penilaian Program Latihan Khidmat Negara (PLKN) Melalui Gagasan Latihan Fizikal. Research Report. Sintok: Universiti Utara Malaysia.

Youniss, J. (2005). Much to learn about new agents of political socialization. Human Development 48: 356-362. 